\title{
Should physicians always rely on estimated glomerular filtration rate without knowing the equation?
}

LETTER

\author{
Fabio Fabbian \\ Dario Priori \\ Alfredo De Giorgi \\ Department of Medical Sciences, \\ Clinica Medica Unit, University \\ Hospital St Anna, University of \\ Ferrara, Ferrara, Italy
}

This article was published in the following Dove Press journal:

Clinical Interventions in Aging

22 August 2017

Number of times this article has been viewed

\section{Dear editor}

We read with interest the paper written by Deskur-Smielecka et $\mathrm{al}^{1}$ who investigated the performance of three equations for valuating renal function in 174 patients, aged 78 years, with different cancer diagnosis. They used Cockcroft-Gault (C-G), Modification of Diet in Renal Disease (MDRD), and Berlin Initiative Study1 (BIS1) equations and found that there is a considerable disagreement between renal function estimation formulas. We also performed two studies evaluating different formulas for the calculation of glomerular filtration rate (GFR) in patients with eating disorders ${ }^{2}$ and in those with type 2 diabetes mellitus (DM). ${ }^{3}$ In the first study, GFR was evaluated in 55 patients with anorexia nervosa and 44 patients with bulimia nervosa using $\mathrm{C}-\mathrm{G}$, Mayo Clinic Quadratic (MAYO), and MDRD equations. Bland-Altman analysis suggested that the three formulae were not in agreement $\mathrm{C}-\mathrm{G}$ formula was inaccurate when it was applied to obese or cachectic subjects, MDRD equation underestimated renal function in subjects with normal-high GFR, while MAYO equation seemed to be a good alternative to the other equations suggesting correct classification of patients. Subsequently, we evaluated 1,686 type 2 DM patients aged 68 years. GFR was estimated by MDRD, MAYO, Chronic Kidney Disease Epidemiology Collaboration (CKD-EPI), and $\mathrm{C}-\mathrm{G}$ formulae. The whole population showed a better renal function when it was evaluated with MAYO and $\mathrm{C}-\mathrm{G}$ formulae, and a worse renal function when it was calculated with MDRD formula. Bland-Altman analysis confirmed that formulae results were not in agreement, especially in the case of high GFR. Deskur-Smielecka et $\mathrm{al}^{1}$ adjusted $\mathrm{C}-\mathrm{G}$ equation using total body weight in underweight patients, ideal body weight in patients with normal body weight, and adjusted body weight in overweight and obese patients. They found that GFR estimated with MDRD equation was the highest, and the mean difference with the other two equations varied from 18 to $12 \mathrm{~mL} / \mathrm{min} / 1.73 \mathrm{~m}^{2}$, confirming our results on the lack of agreement between different equations. However, they found a strong negative correlation between difference in GFR calculated with MDRD and $\mathrm{C}-\mathrm{G}$, and BIS1 and serum creatinine values. The correlation explained the worse performance of MDRD formula in subjects with normal serum creatinine levels.

MDRD and $\mathrm{C}-\mathrm{G}$ equations' performances were compared with measured (125) I-iothalamate GFR in 828 patients with CKD and in 457 potential kidney donors. In CKD patients with GFR $<60 \mathrm{~mL} / \mathrm{min} / 1.73 \mathrm{~m}^{2}$, the MDRD equation performed better than the $\mathrm{C}-\mathrm{G}$ formula. In the kidney donor group, the MDRD equation significantly 
underestimated the measured GFR when compared with the $\mathrm{C}-\mathrm{G}$ formula. Moreover, both the MDRD and $\mathrm{C}-\mathrm{G}$ equations overestimated the strength of the association of GFR with measured serum creatinine. The authors concluded that results derived from MDRD equation could be problematic in healthy individuals. ${ }^{4}$

All data suggest that sensitivity of $\mathrm{C}-\mathrm{G}$ and MDRD equations in diagnosing CKD is lower when GFR is $>60 \mathrm{~mL}$ / $\min / 1.73 \mathrm{~m}^{2}$.

\section{Disclosure}

The authors report no other conflicts of interest in this communication.

\section{References}

1. Deskur-Smielecka E, Kotlinska-Lemieszek A, Chdek J, WieczorowskaTobis K. Assessment of renal function in geriatric palliative care patients - comparison of creatinine-based estimation equations. Clin Interv Aging. 2017;12:977-983.

2. Fabbian F, Pala M, Scanelli G, Manzato E, Longhini C, Portaluppi F. Estimation of renal function in patients with eating disorders. Int J Eat Disord. 2011;44(3):233-237.

3. Fabbian F, Pala M, Monesi M, et al. The estimation of glomerular filtration rate in type 2 diabetic patients may depend on the equation used. Eur Rev Med Pharmacol Sci. 2013;17(20):2791-2797.

4. Poggio ED, Wang X, Greene T, Van Lente F, Hall PM. Performance of the modification of diet in renal disease and Cockcroft-Gault equations in the estimation of GFR in health and in chronic kidney disease. $J \mathrm{Am}$ Soc Nephrol. 2005;16(2):459-466. 


\section{Authors' reply \\ Ewa Deskur-Smielecka ${ }^{1,2}$ \\ Aleksandra Kotlinska-Lemieszek ${ }^{1,2}$ \\ Jerzy Chudek ${ }^{3,4}$ \\ Katarzyna Wieczorowska-Tobis ${ }^{1,2}$}

'Department of Palliative Medicine, Poznan University of Medical Sciences, ${ }^{2}$ Palliative Medicine Unit, University Hospital of Lord's Transfiguration, Poznan, Poland; ${ }^{3}$ Pathophysiology Unit, Department of Pathophysiology, ${ }^{4}$ Department of Internal Medicine and Oncological Chemotherapy, Medical Faculty in Katowice, Medical University of Silesia, Katowice, Poland

Correspondence: Ewa Deskur-Smielecka

Department of Palliative Medicine, Poznan University of Medical Sciences, Hospicjum Palium, os. Rusa 55, 6I-245 Poznan, Poland

Tel/fax +48 6I 8738303

Email edeskur@ump.edu.pl

\section{Dear editor}

The letter from Fabbian et al, in general, supports our findings concerning the disagreement between currently used equations for the estimation of glomerular filtration rate (GFR). We agree that disagreement in the estimation of kidney function was previously found by a number of authors. However, in our paper ${ }^{1}$ we describe this aspect in very specific population - geriatric, palliative care patients - with high prevalence of cachexia and substantial muscle mass loss. Our group has shown some similarities (low creatinine generation) to the group of patients with anorexia nervosa and bulimia nervosa studied by Fabbian et al. ${ }^{2}$ However, it has to be stressed that patients with anorexia nervosa and bulimia nervosa were much younger, and therefore had much better, mostly normal kidney function. The second population analyzed by Fabbian et $\mathrm{al}^{3}$ - diabetic patients - also differ from out cohort, as they were better nourished. Regardless of these differences, the conclusions concerning the disagreement of different methods in the estimation of kidney function are quite similar. Importantly, the disagreement is more clinically significant in older population, including geriatric, palliative care patients, due to much greater prevalence of chronic kidney disease $(\mathrm{CKD})^{4}$ that affects adjusting drug dosage.

Fabbian et al in their letter conclude that sensitivity of Cockcroft-Gault (C-G) and Modification of Diet in Renal Disease (MDRD) equations in diagnosing CKD is lower in subjects with GFR $>60 \mathrm{~mL} / \mathrm{min} / 1.73 \mathrm{~m}^{2}$. This statement, however, is controversial, as MDRD formula should not be used for the estimation of GFR $>60 \mathrm{~mL} / \mathrm{min} / 1.73 \mathrm{~m}^{2}$. Moreover, the process of kidney aging that results in the GFR decline moves the threshold level below $60 \mathrm{~mL} / \mathrm{min} / 1.73 \mathrm{~m}^{2}$, and even $45 \mathrm{~mL} / \mathrm{min} / 1.73 \mathrm{~m}^{2}$ in 80 years old and above. ${ }^{5}$

\section{Disclosure}

The authors report no other conflicts of interest in this communication.

\section{References}

1. Deskur-Smielecka E, Kotlinska-Lemieszek A, Chudek J, WieczorowskaTobis K. Assessment of renal function in geriatric palliative care patients - comparison of creatinine-based estimation equations. Clin Interv Aging. 2017;12:977-983.

2. Fabbian F, Pala M, Scanelli G, Manzato E, Longhini C, Portaluppi F. Estimation of renal function in patients with eating disorders. Int J Eat Disord. 2011;44(3):233-237.

3. Fabbian F, Pala M, Monesi M, et al. The estimation of glomerular filtration rate in type 2 diabetic patients may depend on the equation used. Eur Rev Med Pharmacol Sci. 2013;17(20):2791-2797.

4. Chudek J, Wieczorowska-Tobis K, Zejda J, et al. The prevalence of chronic kidney disease and its relation to socioeconomic conditions in an elderly Polish population: results from the national population-based study PolSenior. Nephrol Dial Transplant. 2014;29(5):1073-1082.

5. KDOQI clinical practice guidelines for chronic kidney disease: evaluation, classification, and stratification. Available from: www2. kidney.org/professionals/KDOQI/guidelines_ckd/toc.htm. Accessed July 12, 2017.

Dove Medical Press encourages responsible, free and frank academic debate. The content of the Clinical Interventions in Aging 'letters to the editor' section does not necessarily represent the views of Dove Medical Press, its officers, agents, employees, related entities or the Clinical Interventions in Aging editors. While all reasonable steps have been taken to confirm the content of each letter, Dove Medical Press accepts no liability in respect of the content of any letter, nor is it responsible for the content and accuracy of any letter to the editor.

Clinical Interventions in Aging

Dovepress

\section{Publish your work in this journal}

Clinical Interventions in Aging is an international, peer-reviewed journal focusing on evidence-based reports on the value or lack thereof of treatments intended to prevent or delay the onset of maladaptive correlates of aging in human beings. This journal is indexed on PubMed Central, MedLine,
CAS, Scopus and the Elsevier Bibliographic databases. The manuscript management system is completely online and includes a very quick and fair peer-review system, which is all easy to use. Visit http://www.dovepress. com/testimonials.php to read real quotes from published authors. 